\title{
Cholinergic Induction of Theta-Frequency Oscillations in Hippocampal Inhibitory Interneurons and Pacing of Pyramidal Cell Firing
}

\author{
C. Andrew Chapman and Jean-Claude Lacaille
}

Centre de Recherche en Sciences Neurologiques et Département de Physiologie, Université de Montréal, Montréal, Québec, H3C 3J7 Canada

\begin{abstract}
Cholinergic and GABAergic medial septal afferents contribute to hippocampal theta activity in part by actions on local interneurons. Interneurons near the border between stratum radiatum and stratum lacunosum-moleculare (LM) display intrinsic membrane potential oscillations at theta frequency when depolarized near threshold. First, whole-cell current-clamp recordings in rat hippocampal slices were used to examine effects of the cholinergic agonist carbachol on biocytin-labeled LM interneurons. At resting membrane potential, cells were depolarized by bath application of $25 \mu \mathrm{M}$ carbachol, and the depolarization was sufficient to induce membrane potential oscillations $(2.4 \pm 0.2 \mathrm{mV})$ that paced cell firing. Carbachol also depolarized LM interneurons in the presence of 6-cyano-7nitroquinoxaline-2,3-dione, ( \pm )-2-amino-5-phosphonopentanoic acid, and bicuculline, indicating that cholinergic depolarization of LM cells does not depend on ionotropic glutamate or $\mathrm{GABA}_{\mathrm{A}}$ synaptic transmission in local circuits. Atropine blocked the
\end{abstract}

depolarization, indicating that muscarinic receptors were involved. Minimal stimulation applied to visually identified LM interneurons was then used to determine if spontaneous activity in CA1 pyramidal cells can be paced by rhythmic inhibition generated by LM cells at theta frequency. Inhibitory postsynaptic potentials evoked in pyramidal cells by single minimal stimulations were followed by rebound depolarizations and action potentials. When trains of minimal stimulation were delivered, membrane potential oscillations of depolarized pyramidal cells followed the stimulation frequency. Minimal stimulation led pyramidal cell firing with an average phase of $177^{\circ}$. Thus, muscarinic induction of theta-frequency membrane potential oscillations in LM interneurons may contribute to the generation of rhythmic inhibition that paces intrinsically generated theta activity in CA1 pyramidal cells.

Key words: hippocampus; lacunosum-moleculare; theta; rhythmic slow activity; interneurons; cholinergic; GABA
Rhythmic synchronization of principal cells in hippocampus and entorhinal cortex generates theta-frequency (4-12 Hz) electroencephalographic activity, and is thought to govern temporal integration of synaptic inputs (Singer, 1993; Buzsáki and Chrobak, 1995) and mechanisms mediating memory formation (Larson et al., 1986; Huerta and Lisman, 1995; Chapman and Racine, 1997; Chapman et al., 1998; Perez et al., 1999). Hippocampal inhibitory interneurons play a central role in theta activity by rhythmically inhibiting pyramidal cells (Leung, 1984; Fox, 1989; Ylinen et al.,

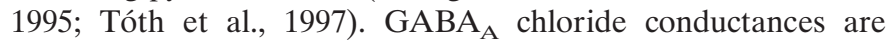
activated during each theta cycle (Fox et al., 1983; Leung and Yim, 1986; Buzsáki et al., 1986; Soltesz and Deschênes, 1993; Ylinen et al., 1995), and rhythmic stimulation of basket and axo-axonic interneurons sets the phase of theta in pyramidal cells in vitro (Cobb et al., 1995).

Different subtypes of hippocampal interneurons (Sik et al., 1995; Freund and Buzsáki, 1996) contribute preferentially to different local circuit interactions and rhythmic activities. Inter-

\footnotetext{
Received May 11, 1999; revised June 18, 1999; accepted June 20, 1999.

This research was funded by a grant to J-C.L. from the Medical Research Council of Canada (MT-10848). J-C.L. is a senior scholar of the Fonds de la Recherche en Santé du Québec (FRSQ), a member of the Groupe de Recherche sur la Système Nerveux Central [Fonds pour la Formation de Chercheurs et l'aide à la Recherche (FCAR)], and a member of an Equipe de recherche from FCAR. C.A.C. was supported by postdoctoral fellowships from the Natural Sciences and Engineering Research Council of Canada and the FRSQ.

Correspondence should be addressed to Dr. Lacaille, Département de Physiologie, Faculté de Médecine, Université de Montréal, C.P. 6128 Succ. Centreville, Montréal, Québec, H3C 3J7 Canada.

Copyright (C) 1999 Society for Neuroscience 0270-6474/99/198637-09\$05.00/0
}

neurons with soma in stratum pyramidale or oriens mediate fast feedback inhibition, fire at high rates (Schwartzkroin and Mathers, 1978; Lacaille et al., 1987; Lacaille and Williams, 1990), and may contribute to both theta (Cobb et al., 1995; Csicsvari et al., 1999) and gamma (Whittington et al., 1995; Wang and Buzsáki, 1996) activity. Interneurons located near the border of strata radiatum and lacunosum-moleculare (LM) receive less spontaneous synaptic input, fire at slower rates (Lacaille and Schwartzkroin, 1988a,b), and mediate slowly decaying dendritic inhibition (Ouardouz and Lacaille, 1997; Banks et al., 1998). When LM cells are depolarized near threshold, they show thetafrequency membrane potential oscillations (Lacaille and Schwartzkroin, 1988a; Williams et al., 1994) generated by an interplay between intrinsic voltage-dependent $\mathrm{Na}^{+}$and $\mathrm{K}^{+}$conductances (Chapman and Lacaille, 1999). Rhythmic inhibition paced by LM cell oscillations may therefore entrain theta activity in pyramidal neurons.

Medial septal afferents drive hippocampal theta activity (Green and Arduini, 1954; Bland and Colom, 1993), and inputs onto interneurons may play a large role. Cholinergic septal afferents contact interneurons and pyramidal cells (Léránth and Frotscher, 1987), and GABAergic inputs target predominantly interneurons (Freund and Antal, 1988; Gulyás et al., 1990). GABAergic afferents may disinhibit pyramidal cells during each theta cycle by inhibiting tonically active interneurons (Tóth et al., 1997). Cholinergic agonists induce theta-like activity in the in vitro hippocampus (Konopacki et al., 1987; MacVicar and Tse, 1989), and cholinergic excitation of interneurons (Reece and 
Schwartzkroin, 1991a; Pitler and Alger, 1992; Behrends and ten Bruggencate, 1993) may help synchronize this activity (Williams and Kauer, 1997; McMahon et al., 1998).

To investigate if cholinergic depolarization of LM interneurons evokes rhythmic inhibition that paces theta activity in pyramidal cells, effects of carbachol on membrane potential oscillations in LM interneurons were examined using whole-cell current-clamp recordings in rat hippocampal slices. The ability of LM cells to regulate theta-frequency activity in pyramidal cells was then assessed by monitoring pyramidal cell activity during minimal stimulation of stratum lacunosum-moleculare.

\section{MATERIALS AND METHODS}

Methods were similar to those reported previously (Chapman and Lacaille, 1999), and all chemicals were obtained from Sigma (St. Louis, MO), unless otherwise indicated.

Hippocampal slices. Hippocampal slices were obtained from 4- to 6-week-old Sprague Dawley rats (Charles River, Montréal, Québec, Canada) anesthetized with halothane (Halocarbon Laboratories, River Edge, NJ). After decapitation, the brain was quickly removed and placed in cold $\left(4^{\circ} \mathrm{C}\right.$ ) artificial CSF (ACSF) containing (in mM) $124 \mathrm{NaCl}, 5 \mathrm{KCl}$, $1.25 \mathrm{NaH}_{2} \mathrm{PO}_{4}, 2 \mathrm{MgSO}_{4}, 2.4 \mathrm{CaCl}_{2}, 26 \mathrm{NaHCO}_{3}$, and 10 dextrose saturated with $95 \% \mathrm{O}_{2}$ and $5 \% \mathrm{CO}_{2}$. Transverse hippocampal slices (300- $\mu$ m-thick) were cut using a vibratome and stored at room temperature for at least $1 \mathrm{hr}$.

Slices were held submerged in a recording chamber and viewed with an upright microscope (Carl Zeiss Axioskop, Jena, Germany) equipped with Hoffman optics (Modulation Optics, Greenvale, NY), a long-range water immersion objective $(40 \times)$, and an infrared video camera (model 6500; Cohu, San Diego, CA). The chamber was perfused with ACSF at room temperature $\left(22^{\circ} \mathrm{C}\right)$ at a rate of $2.5-3.0 \mathrm{ml} / \mathrm{min}$.

Whole-cell recording. Patch pipettes (4-7 M $\Omega$ ) were pulled from borosilicate glass $(1.0 \mathrm{~mm}$ outer diameter $)$ and filled with a solution containing (in mM) $140 \mathrm{~K}$-gluconate, $5 \mathrm{NaCl}, 2 \mathrm{MgCl}_{2}, 10 \mathrm{HEPES}, 0.5$ EGTA, 2 ATP-Tris, 0.4 GTP-Tris, and $0.1 \%$ biocytin, $\mathrm{pH}$ adjusted to $7.2-7.3$ with $\mathrm{KOH}$. Tight seals (2-6 G $\Omega$ ) were obtained on LM interneurons or CA1 pyramidal cells using gentle suction, and whole-cell current-clamp recordings were begun 5 min after break-in. Membrane potential recordings (DC to $3 \mathrm{kHz}$ ) were obtained with an Axoclamp 2A amplifier (Axon Instruments, Foster City, CA), displayed on a digital oscilloscope (model 1604; Gould, Ilford, UK), and digitized for storage on video cassette (NeuroCorder DR-886; NeuroData, New York, NY). Recordings were analog-filtered at $1 \mathrm{kHz}$ (model 900, 8 pole bessel filter; Frequency Devices, Haverville, MA), and digitized at $10 \mathrm{kHz}$ (TL-1; Axon Instruments) for storage on computer hard disk. Recordings were accepted if series resistance was $<50 \mathrm{M} \Omega$ (interneurons: mean, $32.0 \pm 1.5 \mathrm{M} \Omega$; pyramidal cells: mean, $32.6 \pm 4.1 \mathrm{M} \Omega$ ) and input resistance was stable. Series resistance was monitored repeatedly.

Pharmacology. Cholinergic effects on resting membrane potential and firing properties of LM interneurons were assessed with 2-5 min bath applications of the cholinergic agonist carbachol $(25 \mu \mathrm{M})$. Voltagedependent changes in frequency and amplitude of oscillations were monitored using steady current injection to hold LM cells at various membrane potentials relative to spike threshold both before and during carbachol application. Voltage responses to positive and negative current pulses (500 msec duration) were also recorded in the presence and absence of carbachol.

To determine if carbachol-induced depolarization of LM cells results from changes in local circuit synaptic inputs, carbachol was applied 20 min after bath application of 6-cyano-7-nitroquinoxaline-2,3-dione (CNQX; $20 \mu \mathrm{M}),( \pm)$-2-amino-5-phosphonopentanoic acid (AP-5; 50 $\mu \mathrm{M}$; Research Biochemicals, Natick, MA), and bicuculline methiodide $(25 \mu \mathrm{M})$ to block ionotropic glutamate and $\mathrm{GABA}_{\mathrm{A}}$ synaptic transmission. To determine if muscarinic receptors mediate carbachol-induced depolarization, the muscarinic receptor antagonist atropine $(1 \mu \mathrm{M})$ was applied for a $15-20 \mathrm{~min}$ period before adding carbachol.

Minimal stimulation. The impact of inhibition generated by LM cell firing at theta frequency on firing activity in pyramidal neurons was assessed using minimal stimulation in stratum lacunosum-moleculare during whole-cell current-clamp recordings from CA1 pyramidal neurons in the presence of CNQX and AP-5. Bipolar borosilicate theta glass stimulation electrodes (Sutter Instruments) filled with ACSF were placed in stratum lacunosum-moleculare $100-200 \mu \mathrm{m}$ from the soma of visually identified LM interneurons. Stimulation intensity was adjusted (56-128 $\mu \mathrm{A})$ to evoke IPSPs with failure rates of $\sim 33 \%$. Steady positive current injection was used to depolarize pyramidal neurons to induce spontaneous membrane potential oscillations and action potentials. First, single pulses of minimal stimulation were delivered once every $10 \mathrm{sec}$ to characterize IPSPs and their effects on pyramidal cell firing. Then, 2.0 sec duration trains of minimal stimulation were used to determine if firing properties of pyramidal cells may be paced repetitively by minimal stimulation of stratum lacunosum-moleculare. The frequency of minimal stimulation was set to $3 \mathrm{~Hz}$ to match the frequency of spontaneous activity in LM interneurons (Chapman and Lacaille, 1999) and pyramidal cells at $22^{\circ} \mathrm{C}$. Bicuculline $(20 \mu \mathrm{M})$ was added to the bath, and changes in minimal IPSPs at resting membrane potential were monitored to determine $\mathrm{GABA}_{\mathrm{A}}$ receptor involvement.

Analysis. Samples of membrane potential in LM cells were prepared for spectral analysis as described previously (Chapman and Lacaille, 1999) by low-pass filtering at $100 \mathrm{~Hz}$ and reducing the effective sampling rate to $1 \mathrm{kHz}$. Average power spectra were calculated as the squared magnitude of the Fast Fourier Transform using the Origin software package (Microcal, Northampton, MA) based on three $2.048 \mathrm{sec}$ duration segments selected to contain no action potentials. Matched samples $t$ tests were used to compare oscillation peak frequency and power in the $2-5.4 \mathrm{~Hz}$ band in the presence and absence of carbachol. Changes in the firing of pyramidal cells were assessed by measuring latencies of action potentials relative to minimal stimulation. Rhythmicity of pyramidal cell membrane potential was assessed using autocorrelation functions obtained from $2.0 \mathrm{sec}$ duration, digitally filtered $(40 \mathrm{~Hz})$ records of membrane potential recorded just before, and during, trains of minimal stimulation.

Electrophysiological properties of LM interneurons and pyramidal cells were analyzed using the software package pClamp 6.0 (Axon Instruments). Action potential height was measured from resting membrane potential, and action potential duration was measured at the base. Afterhyperpolarization amplitudes were measured relative to the base of action potentials. Input resistance was quantified by the slope of a linear fit of peak voltage responses to current pulses (500 msec duration) ranging from -100 to $0 \mathrm{pA}$ in steps of $10 \mathrm{pA}$. Inward rectification was quantified by expressing the peak input resistance as a proportion (rectification ratio) of steady-state resistance measured at the end of 500 msec duration, $-100 \mathrm{pA}$ current pulses. Membrane time constant was measured by fitting an exponential function to the transient voltage response evoked by small hyperpolarizing current pulses that did not evoke hyperpolarization-activated rectification.

Histology. Detailed histological procedures for revealing biocytin-filled cells have been described previously (Chapman and Lacaille, 1999). Briefly, slices were fixed in $4 \%$ paraformaldehyde in $0.1 \mathrm{~m}$ phosphate buffer, rinsed, and stored at $4^{\circ} \mathrm{C}$ before resectioning to a thickness of 60 $\mu \mathrm{m}$. Sections were treated with $1 \% \mathrm{H}_{2} \mathrm{O}_{2}$, washed in $2.5 \%$ dimethylsulfoxyde and $0.1 \%$ Triton $\mathrm{X}-100$ in $0.1 \mathrm{M}$ phosphate buffer, and incubated in avidin-biotin complex (ABC kit; Vector Laboratories, Burlingame, CA). After rinsing, sections were incubated in $0.05 \% 3^{\prime} 3$ diaminobenzidine $4 \mathrm{HCl}, 0.02 \% \mathrm{NiS}_{4}, 0.1 \mathrm{~m}$ imidazole, and $0.001 \%$ $\mathrm{H}_{2} \mathrm{O}_{2}$ in Tris-buffered saline. Sections were then rinsed and cleared in xylene. Axonal and dendritic arborizations of well-filled cells were traced with a camera lucida.

\section{RESULTS \\ Basic electrophysiology and morphology of LM interneurons}

Stable recordings were obtained from 27 LM cells. Passive electrical properties and firing patterns of LM cells were similar to whole-cell recordings reported previously (Williams et al., 1994; Chapman and Lacaille, 1999). LM cells were typically silent at resting membrane potential (mean, $-55.6 \pm 0.7 \mathrm{mV}$ ), had high input resistances $(283 \pm 18 \mathrm{M} \Omega)$, and long membrane time constants $\left(\tau_{\mathrm{m}}=25.0 \pm 1.7 \mathrm{msec}\right)$. Action potentials (amplitude, $95.6 \pm 0.8 \mathrm{mV}$; duration, $2.8 \pm 0.1 \mathrm{msec}$ ) were typically followed by fast $(9.4 \pm 0.6 \mathrm{mV})$ and medium duration $(12.2 \pm 0.7 \mathrm{mV})$ afterhyperpolarizations. Inward rectification was observed in 13 of 27 cells, and the mean rectification ratio among these cells was $1.12 \pm 0.02$ (range, 1.03-1.25). 


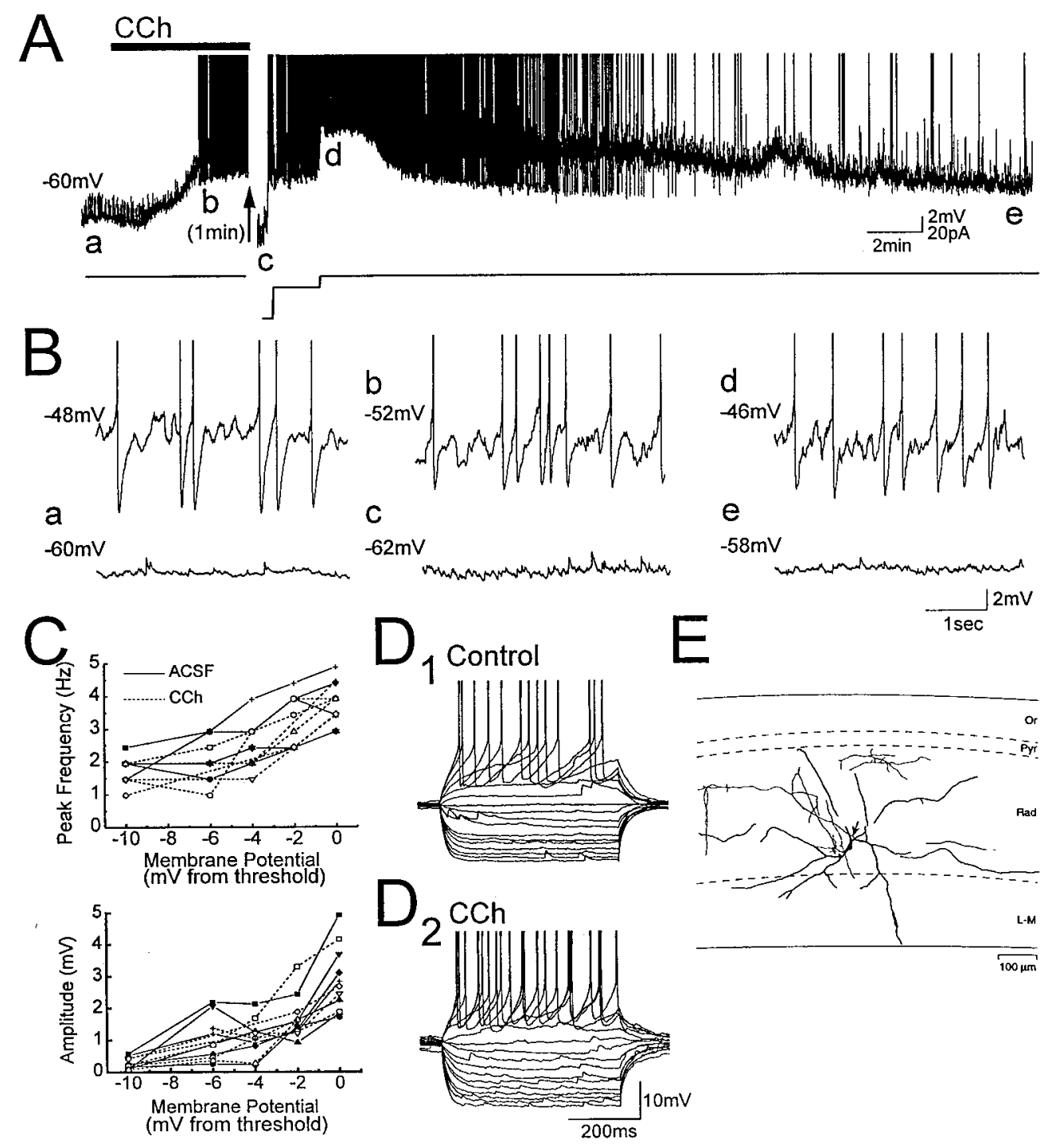

Figure 1. Carbachol depolarizes LM interneurons and induces voltage-dependent membrane potential oscillations. $A, B$, Membrane potential recording from an LM interneuron exposed to the cholinergic agonist carbachol (CCh, solid bar; $25 \mu \mathrm{M})$. Letters in $A$ indicate times from which expanded traces in $B$ were taken, and action potentials are truncated in this and subsequent figures. Voltage-dependent oscillations were induced in the LM cell with positive current injection before carbachol application $(B$, top left trace). Application of carbachol at resting membrane potential $(a)$ was followed by a depolarization that induced oscillations that paced action potentials $(b, d)$. The depolarization was preceded by a small transient hyperpolarization (see also Fig. $2 A$ ). Oscillations induced by carbachol were eliminated when the cell was hyperpolarized with steady negative current injection $(c)$ or when the cell repolarized after washout of carbachol $(e)$, indicating that the oscillations are voltage-dependent. $C$, Power spectral analysis of oscillations in six LM cells in which membrane potential relative to spike threshold was varied using steady current injection. Frequency and amplitude of oscillations, and their voltage dependence, were not significantly different in carbachol (dashed lines) and in normal ACSF (solid lines). D, Voltage responses to positive and negative current pulses that ranged from -100 to $60 \mathrm{pA}$ in $10 \mathrm{pA}$ steps. For this cell, carbachol increased input resistance and decreased afterhyperpolarization amplitude. $E$, Camera lucida tracing of the LM interneuron from which recordings in $A, B$, and $D$ were obtained. The axon is indicated by an arrow. Abbreviations in this figure and in Figure 2: Or, stratum oriens; Pyr, stratum pyramidale; Rad, stratum radiatum; $L-M$, stratum lacunosum-moleculare.

Morphological information was obtained for 21 biocytin-filled LM interneurons. Morphology of LM cells was similar to that reported previously (Williams et al., 1994; Morin et al., 1996; Chapman and Lacaille, 1999) (Figs. 1E, 2C), except that axonal or dendritic arborizations were not observed outside the CA1 area. Also, neuroglioform cells in LM (Vida et al., 1998) were not observed. Somata of LM cells (10-25 $\mu \mathrm{m}$ diameter) were either multipolar (12 cells) or fusiform in shape and oriented parallel to the pyramidal cell layer (nine cells). Cells had between two and five primary dendrites that bifurcated close to the soma and arbourized in stratum radiatum and lacunosum-moleculare. Six multipolar cells had dendrites that extended into stratum oriens. Axonal arbourizations were reconstructed in 14 cells and arborized mainly in stratum radiatum and stratum lacunosummoleculare. Four cells also showed some axonal arbourizations in stratum pyramidale (three cells) and stratum oriens (two cells).

\section{Oscillations in LM interneurons induced by carbachol}

When positive current injection (usually $<40 \mathrm{pA}$ ) was used to hold LM cells near spike threshold, almost all cells (25 of 27 cells) displayed voltage-dependent membrane potential oscillations with a frequency of $2-5 \mathrm{~Hz}$. LM cells fired either single spikes or 


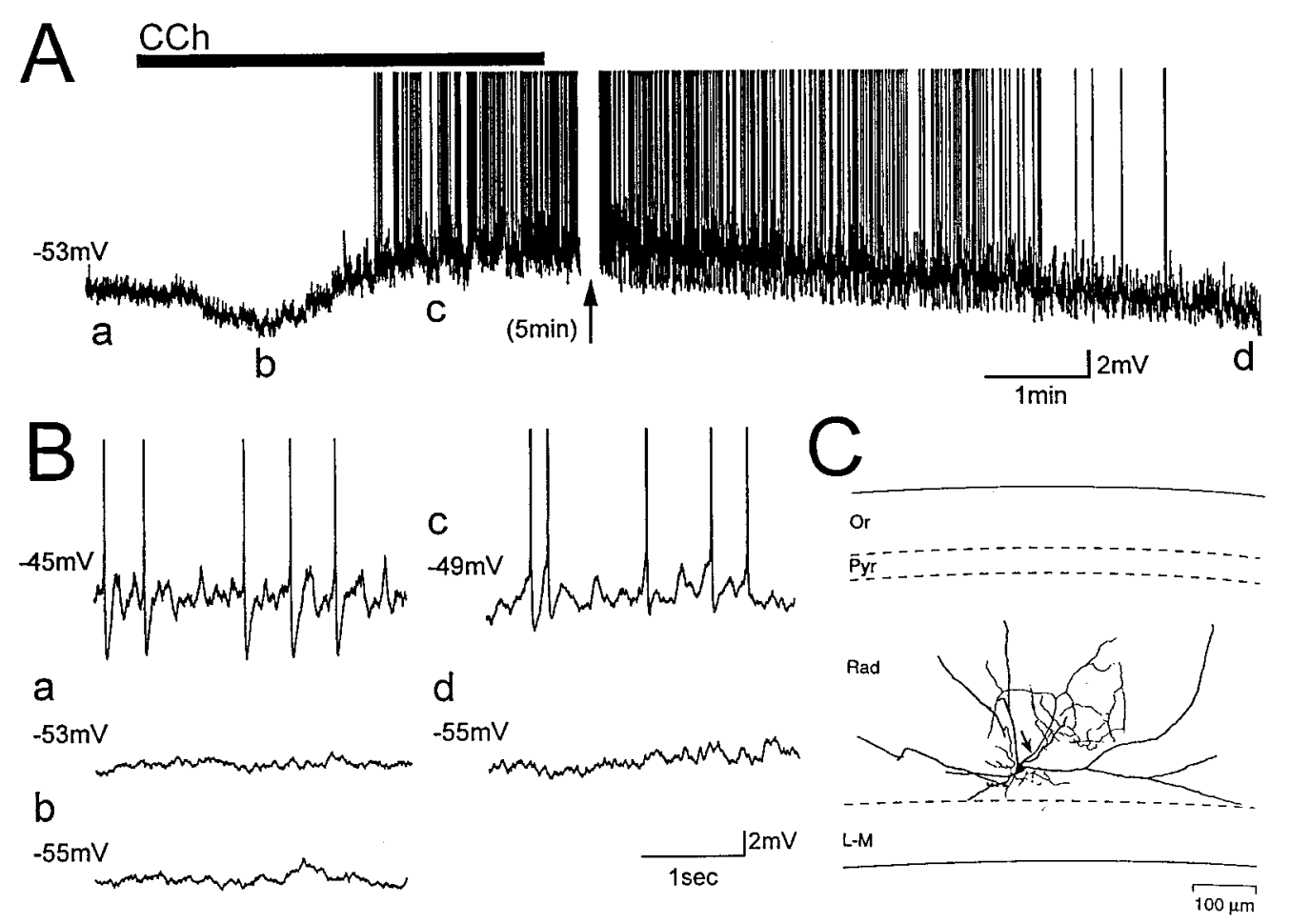

Figure 2. Glutamate and $\mathrm{GABA}_{\mathrm{A}}$ synaptic activity are not necessary for the depolarization of LM interneurons induced by carbachol. $A$, $B$, Membrane potential of an LM interneuron exposed to bath application of $25 \mu \mathrm{M}$ carbachol $(C C h$, solid bar) during blockade of ionotropic glutamate and GABA synaptic transmission with CNQX $(20 \mu \mathrm{M})$, AP-5 $(50 \mu \mathrm{M})$, and bicuculline $(25 \mu \mathrm{M})$. Letters indicate times from which expanded traces in $B$ were taken. Steady current injection induced voltage-dependent oscillations before carbachol application (B, top left trace). Application of carbachol at resting membrane potential $(a)$ was followed by a transient hyperpolarization $(b)$, and then a depolarization that induced oscillations and cell firing $(c)$. $C$, Camera lucida tracing of the LM interneuron from which recordings were obtained. The axon is indicated by an arrow.

clusters of action potentials at the frequency of oscillations (Fig. $1 B$, top left trace).

At resting membrane potential, addition of $25 \mu \mathrm{M}$ carbachol $(\mathrm{CCh})$ to the bath resulted in a depolarization of $1-9 \mathrm{mV}$ (mean, $4.1 \pm 0.7 \mathrm{mV}$ ) in 14 of $16 \mathrm{LM}$ interneurons (Fig. $1 \mathrm{~A}$ ). Depolarizing responses peaked $134 \pm 20 \mathrm{sec}$ (range, 40-225 sec) after application of carbachol. In eight cells, the depolarization was preceded by a transient hyperpolarization of $1-7 \mathrm{mV}$ (mean, $4.2 \pm 0.6 \mathrm{mV}$ ) that peaked at a mean latency of $58 \pm 8 \mathrm{sec}$. The carbachol-induced depolarization was sufficient to result in membrane potential oscillations $(2.4 \pm 0.2 \mathrm{mV}$ peak-to-peak $)$ and action potential generation in 12 cells (Fig. $1 B$, traces $b, d$ ). In three cells, strong depolarizations resulted in high-frequency spiking between 10 and $29 \mathrm{~Hz}$. Membrane potential oscillations during carbachol application were eliminated when cells were repolarized to resting membrane potential with negative current injection, indicating that oscillations induced by carbachol were voltage-dependent (Fig. 1B, trace c). Membrane potential of LM cells returned toward resting membrane potential after 15-20 min washout in normal ACSF (Fig. $1 A, B e$ ).

Oscillations induced by carbachol were similar to those induced in normal ACSF by depolarizing current injection. Oscillations in carbachol and in normal ACSF did not differ with respect to power (control, $2.31 \pm 0.33 \mathrm{mV}^{2} / \mathrm{Hz}$; CCh, $2.18 \pm 0.35 \mathrm{mV}^{2} / \mathrm{Hz}$ ) or peak frequency (control, $3.4 \pm 0.2 \mathrm{~Hz}$; CCh, $3.2 \pm 0.2 \mathrm{~Hz}$ ). Furthermore, when membrane potential was varied systematically with current injection, reductions in oscillation power and frequency as a function of hyperpolarization from spike threshold were similar in both carbachol and in normal ACSF (Fig. 1C).

Changes in input resistance induced by carbachol were not consistent and did not predict the degree of depolarization induced. Input resistance was increased in six cells (range, 8-67\%; mean, $26.6 \pm 9.4 \%$ ), reduced in five cells (range, -6.9 to $-23.8 \%$; mean, $13.1 \pm 3.2 \%$ ), and changed less than $\pm 5 \%$ in five cells. Carbachol also produced no significant changes in amplitude of fast duration afterhyperpolarizations (fAHPs) or medium duration afterhyperpolarizations (mAHPs) in LM cells (fAHP: control, $9.4 \pm 0.6 \mathrm{mV}$; CCh, $8.0 \pm 0.7 \mathrm{mV}$; mAHP: control, $12.2 \pm$ $0.7 \mathrm{mV}$; CCh, $10.5 \pm 0.8 \mathrm{mV}$ ) (Fig. 1D). Carbachol reduces amplitude and increases duration of action potentials in pyramidal neurons (Figenschou et al., 1996) but these changes were not statistically significant in LM interneurons (amplitude: control, $95.6 \pm 0.8 \mathrm{mV} ; \mathrm{CCh}, 92.9 \pm 4.7 \mathrm{mV} ; t_{30}=1.89, p=0.07$; duration: control, $2.8 \pm 0.2 \mathrm{msec}$; $\mathrm{CCh}, 3.0 \pm 0.5 \mathrm{msec} ; t_{30}=1.78$, $p=0.09)$.

\section{Receptors mediating cholinergic depolarization of LM interneurons}

To determine if glutamatergic and GABAergic synaptic activity in local circuits could mediate cholinergic depolarization of LM cells, experiments were also conducted in the presence of the glutamate and $\mathrm{GABA}_{\mathrm{A}}$ receptor blockers CNQX (20 $\left.\mu \mathrm{M}\right)$, AP-5 (50 $\mu \mathrm{M})$, and bicuculline (25 $\mu \mathrm{M} ; n=7$; Fig. 2). In all cells, carbachol induced a depolarization of membrane potential similar in amplitude (range, $2-10 \mathrm{mV}$; mean, $6.1 \pm 1.0 \mathrm{mV}$ ) to that observed in normal ACSF. In three of seven cells, application of carbachol in the presence of these antagonists resulted in an initial transient hyperpolarization (range, 4-10 mV; e.g., Fig. $2 A, B$, compare $a, b)$. The hyperpolarizing and depolarizing responses induced by carbachol therefore do not depend on gluta- 


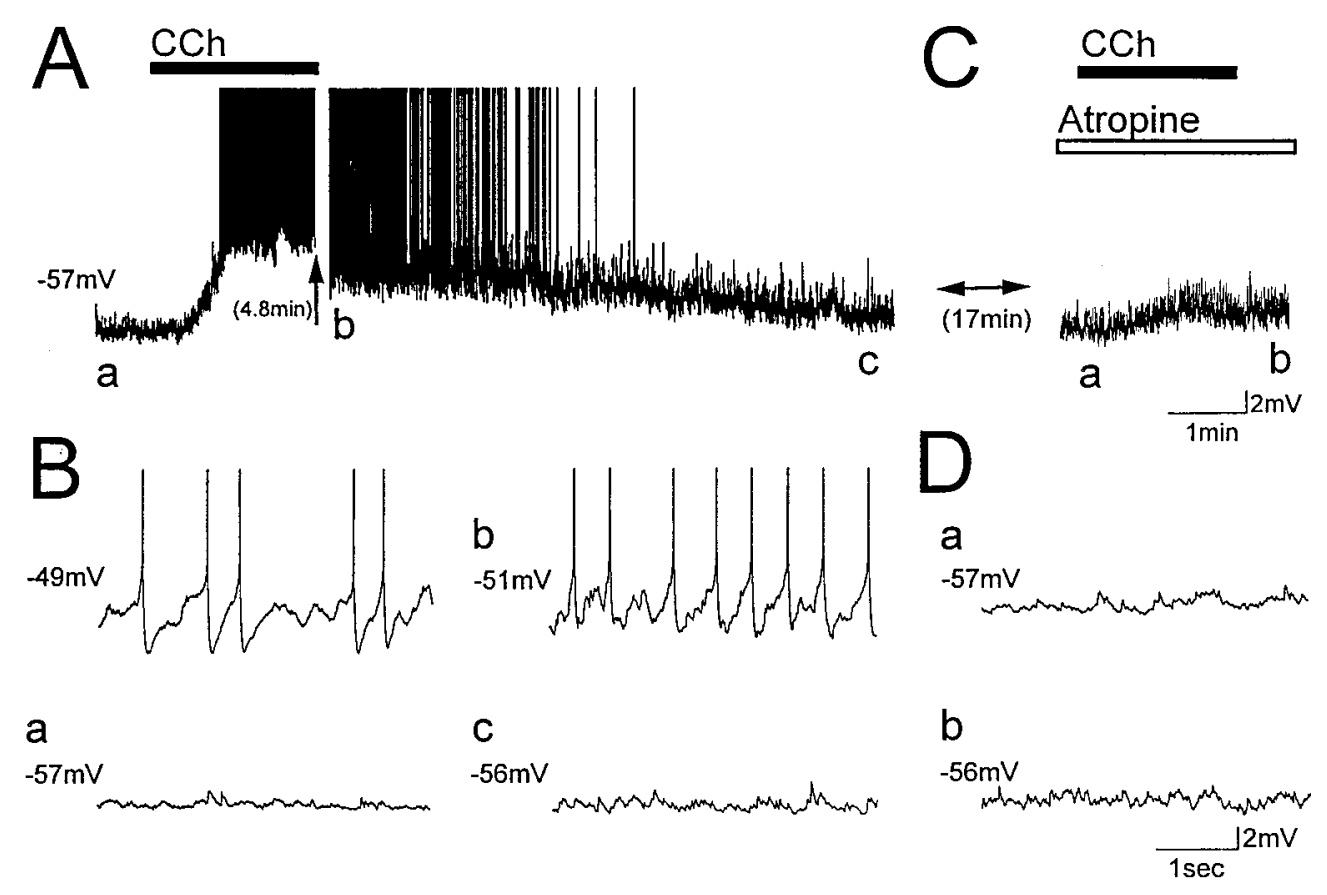

Figure 3. Muscarinic receptors mediate the depolarization of LM interneurons induced by carbachol. Membrane potential of an LM interneuron exposed to a 2 min bath application of $25 \mu \mathrm{M}$ carbachol (CCh, solid bar) in normal $\operatorname{ACSF}(A, B)$ and in the presence of the muscarinic receptor antagonist atropine $(C, D$, open bar; $1 \mu \mathrm{M})$. Letters in $A$ and $C$ indicate times from which the corresponding traces in $B$ and $D$ were taken. Steady current injection induced voltage-dependent oscillations in normal ACSF before carbachol application ( $B$, top left trace). In normal ACSF, carbachol depolarized the cell from resting membrane potential and induced voltage-dependent oscillations and cell firing $(A, a$ vs $b)$. Oscillations were eliminated during washout of carbachol as membrane potential repolarized $(c)$. After exposure to atropine for at least $15 \mathrm{~min}(C, D)$, carbachol did not induce oscillations or cell firing $(C, a$ vs $b)$.

matergic and GABAergic synaptic activity in local circuits. Power and frequency of membrane potential oscillations in CNQX, AP-5, and bicuculline were not different from those recorded in normal ACSF, whether they were induced by positive current injection (frequency, $3.1 \pm 0.3 \mathrm{~Hz}$; power, $2.34 \pm 0.6 \mathrm{mV}^{2} / \mathrm{Hz}$; see also Chapman and Lacaille, 1999) or by carbachol (frequency, $3.1 \pm 0.2 \mathrm{~Hz}$; power, $2.6 \pm 0.7 \mathrm{mV}^{2} / \mathrm{Hz}$ ). Membrane potential of LM cells returned to resting membrane potential following washout of carbachol (Fig. 2A,B, compare $c, d$ ).

To determine if muscarinic receptors on LM interneurons mediate depolarizations induced by carbachol, the muscarinic receptor antagonist atropine $(1 \mu \mathrm{M})$ was added to the bath $15-20$ min before the addition of carbachol. Atropine blocked depolarizations induced by carbachol $(n=5$; Fig. $3 A, B$ vs $C, D$, compare $a, b)$, and the mean change in membrane potential was $-0.8 \pm 0.6$ $\mathrm{mV}$ (range, $-2-2 \mathrm{mV}$ ). Carbachol-induced depolarizations in normal ACSF were therefore mediated by activation of muscarinic cholinergic receptors.

\section{Minimal IPSPs in CA1 pyramidal neurons}

To determine how inhibition generated by LM cells affects firing patterns of pyramidal cells, whole-cell current clamp recordings were obtained from CA1 pyramidal cells in the presence of CNQX and AP-5, and minimal stimulation was applied to stratum lacunosum-moleculare close to visually identified LM interneurons. Biocytin labeling was successful for 8 of the 10 pyramidal cells, and each showed basal and apical dendritic arbourizations characteristic of pyramidal neurons (data not shown; see Morin et al., 1996). Basic electrophysiological characteristics of cells were also consistent with whole-cell recordings from pyramidal neurons (resting membrane potential, $-54.1 \pm$
$0.8 \mathrm{mV}$; input resistance, $144 \pm 7 \mathrm{M} \Omega ; \tau_{\mathrm{m}}=37.3 \pm 2.1 \mathrm{msec}$; rectification ratio, $1.27 \pm 0.02$; action potential amplitude, $95.3 \pm$ $1.4 \mathrm{mV}$; action potential duration, $3.6 \pm 0.1 \mathrm{msec}$; mAHP amplitude, $4.4 \pm 0.8 \mathrm{mV}$ ).

To stimulate inhibitory afferents to pyramidal cells originating from single interneuron fibers in LM, the stimulating electrode was placed near a visually identified LM interneuron, and stimulation intensity was adjusted to evoke IPSPs in pyramidal cells with a large proportion of failures (23-43\%). Minimally evoked IPSPs at resting membrane potential had a mean peak amplitude of $-0.63 \pm 0.06 \mathrm{mV}$, a peak latency of $57 \pm 4 \mathrm{msec}$, and decayed monoexponentially with long decay time constants $(77 \pm 6 \mathrm{msec}$; Fig. $4 A$, bottom trace). Bath application of $25 \mu \mathrm{M}$ bicuculline at the end of experiments blocked minimal IPSPs (eight of eight cells), indicating their dependence on $\mathrm{GABA}_{\mathrm{A}}$ receptor activation.

To determine how minimal IPSPs affect firing behavior of pyramidal cells, single pulses of minimal stimulation were delivered during positive current injection used to depolarize pyramidal cells to action potential threshold. The peak latency of minimal IPSPs $(56 \pm 3 \mathrm{msec})$ was unchanged, but amplitudes of minimal IPSPs in depolarized pyramidal cells $(-1.28 \pm 0.18 \mathrm{mV})$ were roughly twice as large as at resting membrane potential. Action potentials in pyramidal cells were suppressed during the IPSP for a mean duration of $81 \pm 6 \mathrm{msec}$, and the decay of minimal IPSPs was usually followed by a transient rebound depolarization in which membrane potential overshot the mean resting membrane potential to more depolarized levels. On trials in which the IPSP was followed by an action potential, the latency of the first spike was $\sim 250-300$ msec; similar to the peak latency 


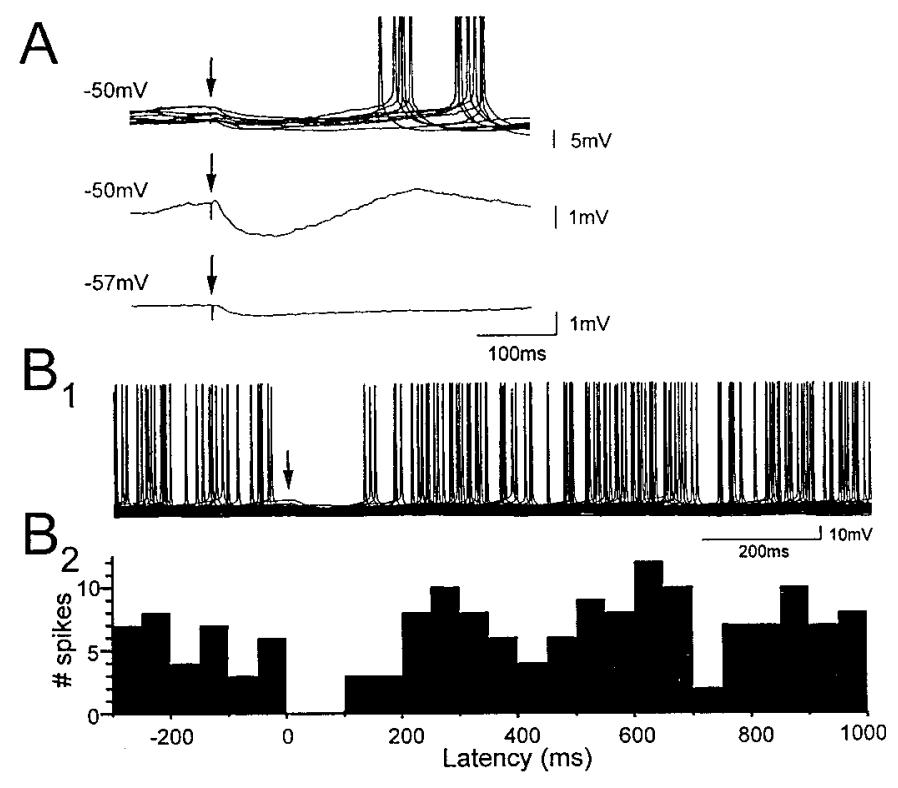

Figure 4. Minimal stimulation in stratum lacunosum-moleculare evokes IPSPs, followed by rebound depolarization and spiking in CA1 pyramidal neurons. $A$, IPSPs evoked in pyramidal cells by minimal stimulation in stratum lacunosum-moleculare (arrows) at membrane potentials indicated at left. Eleven superimposed traces $(A$, top) show minimal IPSPs that were followed by an action potential. Rebound depolarizations at the same latencies as the action potentials were also observed when the cell was held just below spike threshold ( $A$, middle, mean of 12 traces), but not at more hyperpolarized levels ( $A$, bottom, mean of 61 traces). $B_{1}$, Fifty superimposed traces showing the effect of minimally evoked IPSPs (arrow) on firing of the CA1 pyramidal cell. $B_{2}$, The corresponding spike frequency histogram shows peaks at latencies near 250 and $600 \mathrm{msec}$, suggesting that intrinsic mechanisms generating rhythmic membrane potential oscillations in the pyramidal cell are reset by minimal IPSPs generated from stratum lacunosum-moleculare.

of the rebound depolarization (Fig. 4A, top traces). Therefore, single minimal IPSPs first suppressed pyramidal cell firing and then induced a rebound depolarizing response that timed firing of action potentials. Visual inspection of spike frequency histograms identified peaks reflecting the mean latency of rebound action potentials in pyramidal cells $(275 \pm 19 \mathrm{msec} ; n=10$ cells $)$. In 5 of 10 cells there was a second clear peak at a mean latency of $644 \pm 32 \mathrm{msec}$, suggesting that minimal IPSPs generated by LM interneurons can reset intrinsic oscillatory activity pyramidal cells (Fig. 4B).

To determine how repetitive firing of pyramidal cells may be affected by rhythmic inhibition generated by LM interneurons, trains of minimal stimulation were delivered in stratum lacunosum-moleculare close to visually identified LM cells. Two second duration trains were delivered at a frequency of $3 \mathrm{~Hz}$ to match the frequency of spontaneous oscillatory activity in LM cells at $22^{\circ} \mathrm{C}$. The phase of repetitive pyramidal cell firing was strongly affected during trains of minimal stimulation (Fig. 5). Minimal IPSPs generated during the train of minimal stimulation caused an initial depression of cell firing lasting $63 \pm 7 \mathrm{msec}$ on average, and subsequent action potentials were generated with a mean latency of $197 \pm 5 \mathrm{msec}$ relative to pulses in the trains. Peaks in spike frequency histograms (20 msec bins) indicated that action potentials occurred with the highest probability at a mean latency of $164 \pm 12 \mathrm{msec}$. Pyramidal cell firing was therefore generated with a phase relationship of $177^{\circ}$ relative to trains of minimal stimulation at $3 \mathrm{~Hz}$.

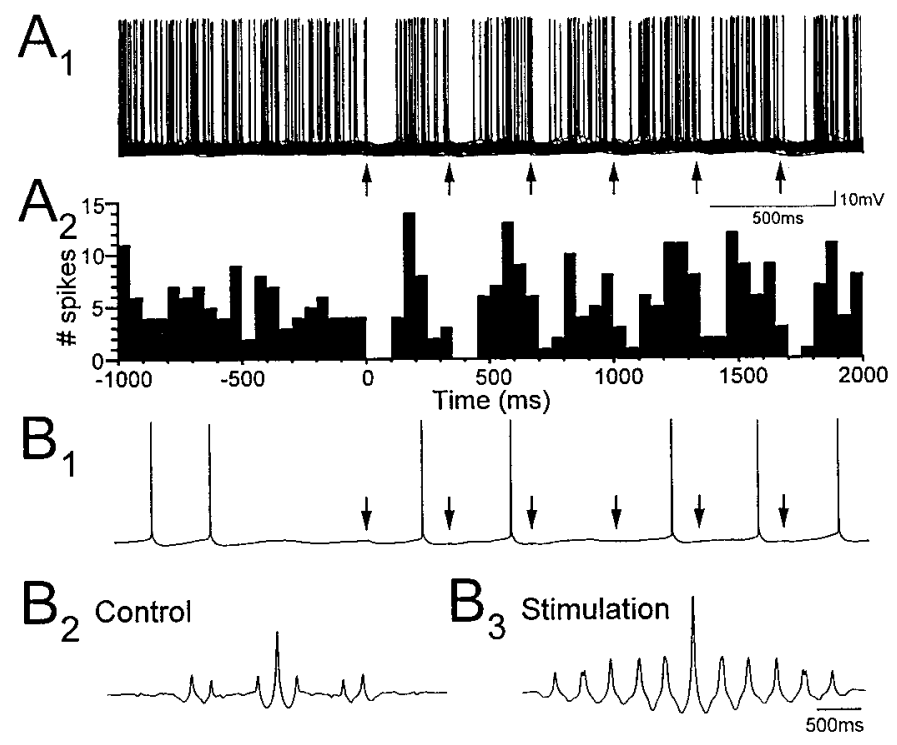

Figure 5. Low-frequency minimal stimulation of stratum lacunosummoleculare paces repetitive firing of pyramidal neurons. $A_{1}$, Seventy superimposed traces showing the effect of a $3 \mathrm{~Hz}$ train of minimal stimulation (arrows) on the firing of a CA1 pyramidal cell depolarized to threshold by steady current injection. $A_{2}$, The corresponding spike frequency histogram shows that the timing of low-frequency spiking in the pyramidal cell is paced throughout the train of minimal stimulation in stratum lacunosum-moleculare. On average, the firing of pyramidal cells was $\sim 180^{\circ}$ out of phase with the minimal stimulation at $3 \mathrm{~Hz}$. $B$, Increased rhythmicity of pyramidal cell firing $\left(B_{1}\right)$ is reflected in autocorrelation functions of $2 \mathrm{sec}$ recordings of membrane potential obtained just before $\left(B_{2}\right)$ and during $\left(B_{3}\right)$ the train of minimal stimulation.

Comparison of autocorrelation functions of $2 \mathrm{sec}$ samples of membrane potential recorded before and during trains of minimal stimulation showed that the trains also enhanced the rhythmicity of low-frequency oscillatory activity in pyramidal cell membrane potential (Fig. $5 B_{1}, B_{2}, B_{3}$ ). Autocorrelation functions were increased in amplitude and showed much more regular peaks for membrane potential recorded during minimal stimulation. Furthermore, peaks in the autocorrelation functions separated by $\sim 333 \mathrm{msec}$ indicated that pyramidal cell membrane potential was entrained to the $3 \mathrm{~Hz}$ stimulation frequency.

\section{DISCUSSION}

Hippocampal CA1 interneurons with their soma near the border of stratum radiatum and stratum lacunosum-moleculare display intrinsic voltage-dependent membrane potential oscillations at theta-frequency that are dependent on an interplay between $\mathrm{Na}^{+}$ and $\mathrm{K}^{+}$conductances (Chapman and Lacaille, 1999). First, we have shown here that LM interneurons are depolarized by the cholinergic agonist carbachol through direct activation of muscarinic receptors on LM cells. Cholinergic depolarization of LM interneurons induced voltage-dependent oscillations that paced cell firing, therefore generating rhythmic inhibitory input to pyramidal cell dendrites. Second, minimal stimulation of stratum lacunosum-moleculare was used to mimic the rhythmic dendritic inhibition generated by LM cells, and minimal IPSPs were found to pace firing patterns of pyramidal neurons. Single minimal stimulations evoked slowly decaying IPSPs that were followed by rebound depolarizations that timed firing of action potentials. Furthermore, the phase of membrane potential oscillations in pyramidal cells was effectively set during trains of minimal stimulation. These results indicate an important role for LM inter- 


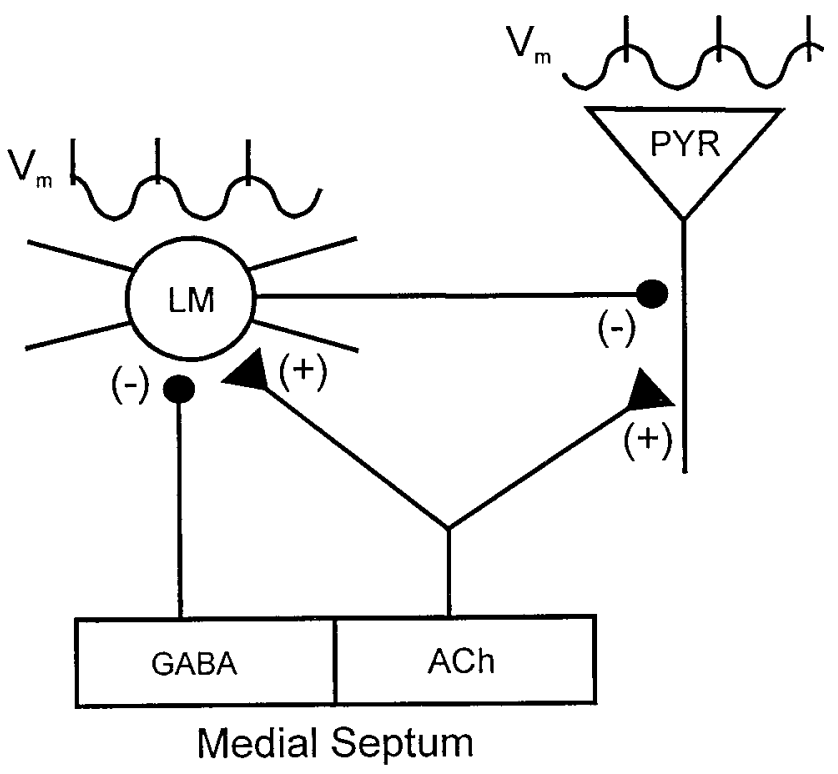

Figure 6. Schematic diagram indicating how LM interneurons can contribute to the pacing of theta activity in CA1 pyramidal neurons. CA1 pyramidal cells $(P Y R)$ are shown to receive excitatory cholinergic inputs $(+)$ from the medial septum, whereas LM interneurons receive both cholinergic and inhibitory GABAergic $(-)$ septal inputs. The proposed relationship between membrane potential $\left(V_{\mathrm{m}}\right)$ in LM cells and pyramidal cells during theta activity is indicated by the traces above each cell. In the model, cholinergic septal afferents depolarize both LM cells and pyramidal cells and induce intrinsic theta-frequency membrane potential oscillations in LM cells that pace action potential generation. Generation of dendritic IPSPs at theta frequency by LM interneurons paces the intrinsic oscillatory activity of the pyramidal cell such that it is $\sim 180^{\circ}$ out of phase with the firing of LM interneurons. Furthermore, because each LM interneuron contacts many pyramidal cells, rhythmic firing of single LM interneurons may synchronize theta activity among large numbers of pyramidal cells. Synchronization of theta-frequency oscillations among LM interneurons may be accomplished in part by GABAergic inputs from the medial septum through a mechanism similar to that proposed for the pacing of theta activity in pyramidal cells by LM interneurons.

neurons in pacing theta activity in pyramidal cells and suggest that the cholinergic activation of LM interneurons may be a powerful mechanism through which the medial septum contributes to the generation of coordinated theta-frequency activity in the hippocampus in vivo (Fig. 6).

\section{Oscillations in LM interneurons induced by carbachol}

Carbachol induced voltage-dependent membrane potential oscillations in LM interneurons by depolarizing membrane potential. The depolarization did not result from cholinergic effects on cells providing major excitatory and inhibitory synaptic inputs to LM interneurons (Cole and Nicoll, 1984; MacVicar and Tse, 1989; McMahon et al., 1998), because the depolarization was not blocked when ionotropic glutamate, and GABA receptors were blocked with CNQX, AP-5, and bicuculline. However, the depolarization was blocked by atropine, indicating that carbachol depolarizes LM interneurons by direct activation of muscarinic receptors. Reece and Schwartzkroin (1991a) also found that carbachol depolarized LM cells in an atropine-sensitive manner that was not blocked by tetrodotoxin. The depolarization described here was sufficient to induce voltage-dependent oscillations that paced cell firing in most of the LM cells sampled.

Ionic mechanisms mediating cholinergic depolarization of LM interneurons are unknown. Carbachol potentiates a low- threshold $\mathrm{Ca}^{2+}$ current in LM interneurons, however, this cannot contribute to the depolarization, because this current is inactivated at resting membrane potential (Fraser and MacVicar, 1991). Carbachol may reduce the M-type $\mathrm{K}^{+}$current $\left(I_{\mathrm{m}}\right)$ that contributes to cholinergic depolarization of CA1 pyramidal cells (Halliwell and Adams, 1982; Madison et al., 1987). Carbachol is unlikely to significantly affect $\mathrm{K}^{+}$conductances mediating oscillations in LM cells (Chapman and Lacaille, 1999) because the power and frequency of oscillations induced in carbachol did not differ from those induced with positive current injection in normal ACSF. Increased input resistance, observed in some LM cells, would be consistent with attenuation of $\mathrm{K}^{+}$conductances by carbachol, but carbachol also depolarized cells in which there was no change or a decrease in input resistance (see also Reece and Schwartzkroin, 1991a). In stellate cells of the entorhinal cortex, muscarinic depolarization is mediated by activation of a $\mathrm{Ca}^{2+}$ dependent cationic conductance; an effect that is also associated with minimal changes in input resistance (Klink and Alonso, 1997a,b).

A transient hyperpolarization after carbachol application preceded the depolarizing response in some cells. Nicotinic receptors are unlikely to contribute because nicotinic activation results in fast inward currents in LM interneurons (Jones and Yakel, 1997; Frazier et al., 1998; McQuiston and Madison, 1999; see Reece and Schwartzkroin, 1991b), and hyperpolarization of LM cells was not observed in atropine (Fig. 3). Direct muscarinic hyperpolarization of interneurons has been observed in cortex (Xiang et al., 1998), and similar mechanisms could occur in LM cells. Alternatively, muscarinic activation of other inhibitory cells (Pitler and Alger, 1992; Behrends and ten Bruggencate, 1993) could contribute to the transient hyperpolarization of LM interneurons, because inhibitory inputs originating from other interneurons (Misgeld and Frotscher, 1986; Williams et al., 1994; Khazipov et al., 1995; Atzori, 1996; Hájos and Mody, 1997) may be activated strongly by carbachol application (McMahon et al., 1998). Hyperpolarizations occurred in both normal ACSF and in the presence of bicuculline (Fig. 2), indicating that $\mathrm{GABA}_{\mathrm{A}}$ receptor activation was not required. However, intense activation of interneurons during carbachol application (McMahon et al., 1998) may be sufficient for activation of $\mathrm{GABA}_{B}$ synaptic inhibition.

\section{Minimal stimulation}

The effects of minimal stimulation demonstrated that single fiber IPSPs from interneurons activated in stratum lacunosummoleculare can have powerful effects on firing properties of CA1 pyramidal cells. Similar to results reported previously for basket and axoaxonic cells (Cobb et al., 1995), minimal stimulation in stratum lacunosum-moleculare evoked IPSPs that resulted in rebound action potentials in pyramidal cells. In contrast to basket and axoaxonic cells that provide inhibition to the soma and initial segment pyramidal cells (Halasy et al., 1996), axons of LM cells arborize primarily in apical dendritic fields (Kunkel et al., 1988) and mediate a more slowly decaying inhibition (Ouardouz and Lacaille, 1997; Banks et al., 1998). It is shown here that dendritic inhibition generated by interneurons activated in stratum lacunosum-moleculare is also effective in inducing rebound depolarization and spiking in pyramidal cells (see also Lacaille and Schwartzkroin, 1988b, their Fig. 4A).

When low-frequency minimal stimulation was used to mimic rhythmic inhibition generated by LM interneurons, the repetitive spiking of pyramidal cells was set to $\sim 180^{\circ}$ out of phase with the 
activation of interneurons by minimal stimulation. Intrinsic conductances generate theta-frequency membrane potential oscillations in pyramidal cells (Nuñez et al., 1987; Leung and Yim, 1991; Garcia-Munoz et al., 1993; Cobb et al., 1995), and IPSPs generated by activation of basket and axoaxonic cells can pace and synchronize these oscillations (Cobb et al., 1995). It is shown here that the dendritic inhibition activated by interneurons in stratum lacunosum-moleculare can also pace oscillations at thetafrequency in pyramidal cells. Furthermore, because membrane potential of LM cells oscillates at theta-frequency in response to depolarization, and IPSPs generated by LM cells decay with a time constant of approximately one-half of the duration of the theta cycle, this interneuronal subtype may play a more specialized role in the pacing of theta activity than other interneuron types.

\section{Functional relevance to theta activity}

Inhibitory circuits of the hippocampus contribute significantly to theta-frequency activity in pyramidal neurons (Leung, 1984; Fox, 1989; Cobb et al., 1995; Ylinen et al., 1995; Tóth et al., 1997). Cholinergic depolarization of LM cells leading to intrinsic thetafrequency oscillations and rhythmic inhibition of pyramidal neurons may be a significant mechanism through which the medial septum contributes to the generation of hippocampal theta activity. This role for LM cells differs markedly from the role of other interneuronal subtypes in which tonic firing is thought to be reduced during theta by GABAergic septal afferents (Bland and Colom, 1993; Bland et al., 1999) and in which phasic septal inhibition may result in phasic disinhibition of pyramidal cells (Tóth et al., 1997). Furthermore, because LM interneurons primarily inhibit dendrites rather than the soma of pyramidal cells, they can provide dendritic inhibition that can effectively modulate dendritic depolarization mediated by direct entorhinal cortex inputs to the CA1 region (Witter et al., 1988; Kamondi et al., 1998). LM cells may also effectively modify levels of dendritic excitability that govern the phase-dependent induction of longterm synaptic potentiation or depression during cholinergically induced oscillations (Huerta and Lisman, 1995).

To provide rhythmic theta-frequency inhibition of large populations of pyramidal cells, the activity of multiple LM interneurons must be closely phase-related. Theta-frequency activity may be synchronized in multiple LM cells through a number of mechanisms including feedforward inputs from CA3 pyramidal cells and the contralateral CA1 region (Kunkel et al., 1988), mutual inhibition among interneurons (Atzori, 1996), and afferents from the entorhinal cortex (Kunkel et al., 1988). A most significant factor, however, is likely to be phasic inputs from medial septal GABAergic inhibitory inputs (Freund and Antal, 1988; Gulyás et al., 1990).

In conclusion, the results presented here strongly suggest that septal cholinergic efferents contribute to theta activity in the CA1 region in part by causing muscarinic depolarization of LM interneurons and inducing theta-frequency firing in LM cells caused by activation of intrinsic membrane potential oscillations (Chapman and Lacaille, 1999). The resulting rhythmic inhibition generated by LM cells can cause rebound action potentials in pyramidal cells and set the phase of intrinsic theta-frequency oscillations in pyramidal cells. Cholinergic induction of thetafrequency oscillations in LM interneurons leading to rhythmic inhibition of pyramidal cells may therefore be an important mechanism through which the medial septum modulates and paces hippocampal theta activity in vivo.

\section{REFERENCES}

Atzori M (1996) Pyramidal cells and stratum lacunosum-moleculare interneurons in the CA1 hippocampal region share a GABAergic spontaneous input. Hippocampus 6:72-78.

Banks MI, Li T-B, Pearce RA (1998) The synaptic basis of GABA Aslow. $_{\text {. }}$. J Neurosci 18:1305-1317.

Behrends JC, ten Bruggencate G (1993) Cholinergic modulation of synaptic inhibition in the guinea pig hippocampus in vitro: excitation of GABAergic interneurons and inhibition of GABA-release. J Neurophysiol 69:626-629.

Bland BH, Colom LV (1993) Extrinsic and intrinsic properties underlying oscillation and synchrony in limbic cortex. Prog Neurobiol 41:157-208.

Bland BH, Oddie SD, Colom LV (1999) Mechanisms of neural synchrony in the septohippocampal pathways underlying hippocampal theta generation. J Neurosci 19:3223-3237.

Buzsáki G, Chrobak JJ (1995) Temporal structure in spatially organized neuronal ensembles: a role for interneuronal networks. Curr Opin Neurobiol 5:504-510.

Buzsáki G, Czopf J, Kondákor I, Kellényi L (1986) Laminar distribution of hippocampal rhythmic slow activity (RSA) in the behaving rat: current-source density analysis, effects of urethane and atropine. Brain Res 365:125-137.

Chapman CA, Lacaille J-C (1999) Intrinsic theta-frequency membrane potential oscillations in hippocampal CA1 interneurons of stratum lacunosum-moleculare. J Neurophysiol 81:1296-1307.

Chapman CA, Racine RJ (1997) Piriform cortex efferents to the entorhinal cortex in vivo: kindling-induced potentiation and the enhancement of long-term potentiation by low-frequency piriform cortex or medial septal stimulation. Hippocampus 7:257-270.

Chapman CA, Perez Y, Lacaille J-C (1998) Effects of GABA A inhibition on the expression of long-term potentiation in CA1 pyramidal cells are dependent on tetanization parameters. Hippocampus 8:289-298.

Cobb SR, Buhl EH, Halasy K, Paulsen O, Somogyi P (1995) Synchronization of neuronal activity in hippocampus by individual GABAergic interneurons. Nature 378:75-78.

Cole AE, Nicoll RA (1984) The pharmacology of cholinergic excitatory responses in hippocampal pyramidal cells. Brain Res 305:283-290.

Csicsvari J, Hirase H, Czurkó A, Mamiya A, Buzsáki G (1999) Oscillatory coupling of hippocampal pyramidal cells and interneurons in the behaving rat. J Neurosci 19:274-287.

Figenschou A, Hu G-Y, Storm JF (1996) Cholinergic modulation of the action potential in rat hippocampal neurons. Eur J Neurosci 8:211-219.

Fox SE (1989) Membrane potential and impedance changes in hippocampal pyramidal cells during theta rhythm. Exp Brain Res 77:283-294.

Fox SE, Wolfson S, Ranck Jr JB (1983) Investigating the mechanisms of hippocampal theta rhythms: approaches and progress. In: Neurobiology of the hippocampus (W Siefert, ed), pp 303-319. New York: Academic.

Fraser DD, MacVicar BA (1991) Low-threshold transient calcium current in rat hippocampal lacunosum-moleculare interneurons: kinetics and modulation by neurotransmitters. J Neurosci 11:2812-2820.

Frazier CJ, Rollins YD, Breese CR, Leonard S, Freedman R, Dunwiddie TV (1998) Acetylcholine activates an $\alpha$-bungarotoxin-sensitive nicotinic current in rat hippocampal interneurons, but not pyramidal cells. J Neurosci 18:1187-1195.

Freund TF, Antal M (1988) GABA-containing neurons in the septum control inhibitory interneurons in the hippocampus. Nature 336:170-173.

Freund TF, Buzsáki G (1996) Interneurons of the hippocampus. Hippocampus 6:347-470.

Garcia-Munoz A, Barrio LC, Buno W (1993) Membrane potential oscillations in CA1 hippocampal pyramidal neurons in vitro: intrinsic rhythms and fluctuations entrained by sinusoidal injected current. Exp Brain Res 97:325-333.

Green JD, Arduini AA (1954) Hippocampal electrical activity in arousal. J Neurophysiol 17:403-420.

Gulyás AI, Görcs TJ, Freund TF (1990) Innervation of different peptidecontaining neurons in the hippocampus by GABAergic septal afferents. Neuroscience 37:31-44.

Hajos N, Mody I (1997) Synaptic communication among hippocampal interneurons: properties of spontaneous IPSCs in morphologically identified cells. J Neurosci 17:8427-8442.

Halasy K, Buhl EH, Lörinczi Z, Tamás G, Somogyi P (1996) Synaptic target selectivity and input of GABAergic basket and bistratified inter- 
neurons in the CA1 area of the rat hippocampus. Hippocampus 6:306-329.

Halliwell JV, Adams PR (1982) Voltage-clamp analysis of muscarinic excitation in hippocampal neurons. Brain Res 250:71-92.

Huerta PT, Lisman JE (1995) Bidirectional synaptic plasticity induced by a single burst during cholinergic theta oscillation in CA1 in vitro. Neuron 15:1053-1063.

Jones S, Yakel JL (1997) Functional nicotinic ACh receptors on interneurons in the rat hippocampus. J Physiol (Lond) 504:603-610.

Kamondi A, Acsády L, Wang X-J, Buzsáki G (1998) Theta oscillations in somata and dendrites of hippocampal pyramidal cells in vivo: activitydependent phase-precession of action potentials. Hippocampus $8: 244-261$.

Khazipov R, Congar P, Ben-Ari Y (1995) Hippocampal CA1 lacunosum-moleculare interneurons: modulation of monosynaptic GABAergic IPSCs by presynaptic $\mathrm{GABA}_{\mathrm{B}}$ receptors. J Neurophysiol 74:2126-2137.

Klink R, Alonso A (1997a) Muscarinic modulation of the oscillatory and repetitive firing properties of entorhinal cortex layer II neurons. J Neurophysiol 77:1813-1828.

Klink R, Alonso A (1997b) Ionic mechanisms of muscarinic depolarization in entorhinal cortex layer II neurons. J Neurophysiol 77:1829-1843.

Konopacki J, MacIver MB, Bland BH, Roth SH (1987) Carbacholinduced EEG theta activity in hippocampal brain slices. Brain Res 405:196-198.

Kunkel DD, Lacaille J-C, Schwartzkroin PA (1988) Ultrastructure of stratum lacunosum-moleculare interneurons of hippocampal CA1 region. Synapse 2:382-394.

Lacaille J-C, Schwartzkroin PA (1988a) Stratum lacunosum-moleculare interneurons of hippocampal CA1 region. I. Intracellular response characteristics, synaptic responses, and morphology. J Neurosci 8:1400-1410.

Lacaille J-C, Schwartzkroin PA (1988b) Stratum lacunosum-moleculare interneurons of hippocampal CA1 region. II. Intrasomatic and intradendritic recordings of local circuit synaptic interactions. J Neurosci 8:1411-1424.

Lacaille J-C, Williams S (1990) Membrane properties of interneurons in stratum oriens-alveus of the CA1 region of rat hippocampus in vitro. Neuroscience 36:349-359.

Lacaille J-C, Mueller AL, Kunkel DD, Schwartzkroin PA (1987) Local circuit interactions between oriens/alveus interneurons and CA1 pyramidal cells in hippocampal slices: electrophysiology and morphology. J Neurosci 7:1979-1993.

Larson J, Wong D, Lynch G (1986) Patterned stimulation at the theta frequency is optimal for the induction of hippocampal long-term potentiation. Brain Res 368:347-350.

Léránth C, Frotscher M (1987) Cholinergic innervation of hippocampal GAD- and somatostatin-immunoreactive commissural neurons. J Comp Neurol 261:33-47.

Leung LW (1984) Model of gradual phase shift of theta rhythm in the rat. J Neurophysiol 52:1051-1065.

Leung L-W S, Yim C-Y (1986) Intracellular records of theta rhythm in hippocampal CA1 cells of the rat. Brain Res 367:323-327.

Leung L-W S, Yim C-Y (1991) Intrinsic membrane potential oscillations in hippocampal neurons in vitro. Brain Res 553:261-274.

MacVicar BA, Tse FWY (1989) Local neuronal circuitry underlying cholinergic rhythmical slow activity in CA3 area of rat hippocampal slices. J Physiol (Lond) 417:197-212.

Madison DV, Lancaster B, Nicoll RA (1987) Voltage clamp analysis of cholinergic action in the hippocampus. J Neurosci 7:733-741.

McMahon LL, Williams JH, Kauer JA (1998) Functionally distinct groups of interneurons identified during rhythmic carbachol oscillations in hippocampus in vitro. J Neurosci 18:5640-5651.

McQuiston AR, Madison DV (1999) Nicotinic receptor activation ex- cites distinct subtypes of interneurons in the rat hippocampus. J Neurosci 19:2887-2896.

Misgeld U, Frotscher M (1986) Postsynaptic-GABAergic inhibition of non-pyramidal neurons in the guinea-pig hippocampus. Neuroscience 19:193-206.

Morin F, Beaulieu C, Lacaille J-C (1996) Membrane properties and synaptic currents evoked in CA1 interneuron subtypes in rat hippocampal slices. J Neurophysiol 76:1-16.

Nuñez A, García-Austt E, Buño WJ (1987) Intracellular theta-rhythm generation in identified hippocampal pyramids. Brain Res 416:289-300.

Ouardouz M, Lacaille J-C (1997) Properties of unitary IPSCs in hippocampal pyramidal cells originating from different types of interneurons in young rats. J Neurophysiol 77:1939-1949.

Perez Y, Chapman CA, Woodhall GL, Robitaille R, Lacaille J-C (1999) Differential induction of long-lasting potentiation of inhibitory postsynaptic potentials by theta patterned stimulation versus $100 \mathrm{~Hz}$ tetanization in hippocampal pyramidal cells in vitro. Neuroscience 90:747-757.

Pitler TA, Alger BE (1992) Cholinergic excitation of GABAergic interneurons in the rat hippocampal slice. J Physiol (Lond) 450:127-142.

Reece LJ, Schwartzkroin PA (1991a) Effects of cholinergic agonists on two non-pyramidal cell types in rat hippocampal slices. Brain Res 566:115-126.

Reece LJ, Schwartzkroin PA (1991b) Nicotine exerts differential effects on different CA1 hippocampal cell types. Brain Res 540:287-290.

Schwartzkroin PA, Mathers LH (1978) Physiological and morphological identification of a non-pyramidal hippocampal cell type. Brain Res 157:1-10.

Sik A, Penttonen M, Ylinen A, Buzsáki G (1995) Hippocampal CA1 interneurons: an in vivo intracellular labeling study. J Neurosci 15:6651-6665.

Singer W (1993) Synchronization of cortical activity and its putative role in information processing and learning. Annu Rev Physiol 55:349-374.

Soltesz I, Deschênes M (1993) Low- and high-frequency membrane potential oscillations during theta activity in CA1 and CA3 pyramidal neurons of the rat hippocampus under ketamine-xylazine anesthesia. J Neurophysiol 70:97-116.

Tóth K, Freund TF, Miles R (1997) Disinhibition of rat hippocampal pyramidal cells by GABAergic afferents from the septum. J Physiol (Lond) 500:463-474.

Vida I, Halasy K, Szinyei C, Somogyi P, Buhl EH (1998) Unitary IPSPs evoked by interneurons at the stratum radiatum-stratum lacunosummoleculare border in the CA1 area of rat hippocampus in vitro. J Physiol (Lond) 506:755-773.

Wang X-J, Buzsáki G (1996) Gamma oscillation by synaptic inhibition in a hippocampal interneuronal network model. J Neurosci 16:6402-6413.

Whittington MA, Traub RD, Jefferys JGR (1995) Synchronized oscillations in interneuron networks driven by metabotropic glutamate receptor activation. Nature 373:612-615.

Williams JH, Kauer JA (1997) Properties of carbachol-induced oscillatory activity in rat hippocampus. J Neurophysiol 78:2631-2640.

Williams S, Samulack DD, Beaulieu C, Lacaille J-C (1994) Membrane properties and synaptic responses of interneurons located near the stratum lacunosum-moleculare/radiatum border of area CA1 in wholecell recordings from rat hippocampal slices. J Neurophysiol 71:2217-2235.

Witter MP, Griffioen AW, Jorritsma-Byham B, Krijnen JLM (1988) Entorhinal projections to the hippocampal CA1 region in the rat: an underestimated pathway. Neurosci Lett 85:193-198.

Xiang Z, Huguenard JR, Prince DA (1998) Cholinergic switching within neocortical inhibitory networks. Science 281:985-988.

Ylinen A, Soltész I, Bragin A, Penttonen M, Sik A, Buzsáki G (1995) Intracellular correlates of hippocampal theta rhythm in identified pyramidal cells, granule cells, and basket cells. Hippocampus 5:78-90. 